\title{
EARLY DETECTION OF POTENTIAL CHRONIC ALCOHOLISM BY DETERMINING THE LEVEL OF IGA, MCV AND TRANSFERRIN
}

\author{
Muhamed Sarvan ${ }^{1}$, Sonja Ketin², Radmila Maksimović ${ }^{1}$, Rade Biočanin ${ }^{1}$
}

\begin{abstract}
The level of IgA, transferrin, and the MCV and the ratio of IgA/transferrin were used for the detection of parameters of chronic alcoholism and in parallel, the GGT activity was measured. Three groups of subjects were processed for this study: healthy subjects $(N=18)$, chronic alcoholics $(\mathrm{N}=20)$ treated chronic alcoholics $(\mathrm{N}=15)$, and finally, a group of workers who are employed at the plant spirits $(\mathrm{N}=15)$. A nonparametric Mann-Whitney $U$ test was used to process the obtained values. There were no significant differences between treated alcoholics and healthy subjects in all parameters tested (mean value with an AA: $\operatorname{IgA}=2.9 \mathrm{~g} / \mathrm{L}$, $\mathrm{MCV}=93.8$, transferrin $=3.1 \mathrm{~g} / \mathrm{L}, \mathrm{IgA} /$ transferrin $=0.92, \mathrm{GGT}=11.4 \mathrm{U} / \mathrm{L}$; healthy subjects: $\mathrm{IgA}=2.83 \mathrm{~g} / \mathrm{L}, \mathrm{MCV}=93.6$, transferrin $=3.2 \mathrm{~g} / \mathrm{L}, \mathrm{IgA} /$ transferrin $=0.9, \mathrm{GGT}=7.1 \mathrm{U} / \mathrm{L})$. In the group of untreated alcoholics, IgA values, MCV, and IgA/transferrin ratio were increased as well as the GGT activity (as expected) compared to healthy and treated alcoholics (alcoholics: IgA = $5.1 \mathrm{~g} / \mathrm{L}, \mathrm{MCV}=101$, transferrin $=2.78 \mathrm{~g} / \mathrm{L}, \mathrm{IgA} /$ transferrin $=1.74, \mathrm{GGT}=101.4 \mathrm{U} / \mathrm{L}$ ). Regarding the workers employed in the factory of alcoholic beverages, the level of MCV was significantly higher than in healthy individuals and that value was close to that in alcoholics $(\operatorname{IgA}=1.95 \mathrm{~g} / \mathrm{L}$, $\mathrm{MCV}=99.6$, transferrin $=2.8 \mathrm{~g} / \mathrm{L}, \mathrm{IgA} /$ transferrin $=1.14, \mathrm{GGT}=18.7 \mathrm{U} / \mathrm{L}$ ). The concentration of transferrin was reduced in workers, so the ratio of IgA/transferrin is slightly higher than in healthy individuals, but without a significant difference. It can be seen that the results of the examined parameters may help not only to detect chronic alcoholics but also for monitoring the treatment, given the fact that, paradoxically, many alcoholics use alcohol while under treatment.
\end{abstract}

Acta Medica Medianae 2020;59(1):60-63.

Key words: chronic disease, alcoholism, erythrocyte indices, MCV, transferrin, IgA, early detection

\footnotetext{
${ }^{1}$ Faculty of Pharmacy and Health, Travnik, Bosnia and Herzegovina

${ }^{2}$ Faculty of Maritime Academic Studies Belgrade, Serbia
}

Contact: Sonja Ketin

7 Vojvoda Putnik Blvd., 11000 Belgrade, Serbia

E-mail: ketin.sonja@gmail.com

\section{Introduction}

Alcoholism is one of the most important problems of modern society because of its health and social consequences. Alcohol exerts harmful effects on the human body, causes psychopathological changes, neurological diseases, as well as organic changes in the cardiac muscle, especially in the stomach and liver. The social consequences of alcohol abuse are manifested in all aspects of life and work. One first starts in the family and the im- mediate social environment of alcoholics, and then expands to a broader, particularly work environment. Thus, alcoholism is not an isolated, personal problem or matter for the individual alcoholic, but a problem of the whole family and the social group in which the patient lives and works. Recent statistics show that alcoholism is the third most common disease in men.

The rich vineyard of the parish of Aleksandrovac is a significant producer and consumer of alcoholic beverages. The increased number of cases of chronic alcoholism in the municipality of Kruševac has led to the inclusion of a Clinic for mental health to provide treatment for people addicted to alcohol. The group family therapy was chosen as the most effective type of treatment, and the Club of Treated Alcoholics was formed, in the period from 1987 to 1990, and it included 142 patients. Of this number, 67 patients were cured without recurrence, $20 \mathrm{pa}$ tients with recurrence, and 45 patients left the treatment. Since then, 48 other regular Club members have been cured. The success of the family group therapy was $45.53 \%$, which encourages and promotes the further work of the Club, as a reputable 
institution with success in the treatment of about $70 \%$.

Somatic treatment of patients included a laboratory test to determine the general health of patients. Since it is often difficult to detect chronic alcoholism, and bearing in mind the fact that many alcoholics used alcohol while under treatment, we have included laboratory and processing parameters that are used for the detection of alcoholism: the activity of gamma-glutamyl transferase (GGT) levels, levels of immunoglobulin A (IgA) and serum transferrin, MCV and relationship IgA/transferrin. The aim was to determine which of these laboratory parameters could be most effectively used to detect chronic alcoholism $(1,2)$.

\section{Materials and methods}

Four groups of patients were determined for this study: chronic alcoholics $(\mathrm{N}=20)$ treated chronic alcoholics, club members treated alcoholics $(N=15)$, a group of workers who are employed in the factory of alcoholic beverages $(\mathrm{N}=15)$, and finally a group of healthy individuals which do not consume alcohol $(\mathrm{N}=18)$, and the non-parametric Mann-Whitney $U$ test was used to compare the obtained values.

The people who took part in the testing were chronic alcoholics who consumed alcohol for 15 years, treated alcoholics who consumed alcohol for
10 years, and workers who were exposed to ethanol for 11 years. In all subjects the following parameters were determined:

- GGT enzyme activity was determined by enzyme-kinetic color test from YUGOMEDIC by the method of Szasz's. GGT catalyzes the transfer of the gamma-glutamyl group of L-gamma-glutamyl-3carboxy-4-nitro-anilide to glycylglycine. The color intensity was measured by creating a speed of 5amino-2-nitrobenzoate at $405 \mathrm{~nm}$ at the temperature of $30^{\circ} \mathrm{C}$ and it is proportional to the GGT activity in the sample. Reference values range from 4 to $28 \mathrm{IU} / \mathrm{L}$.

- MCV was obtained from the processing of complete blood count on reading Culter JS. Reference values range from 82 to $97 \mathrm{fl}$.

- IgA (immunoglobulin A) and transferrin were determined by radial immunodiffusion on plates from Behring Werke Corporation, using the method of Mancini. Reference values for the IgA range from 0.90 to $4.50 \mathrm{~g} / \mathrm{L}$ and transferrin from 2,00 to $4,00 \mathrm{~g} / \mathrm{L}$.

\section{Results}

Long-term use of alcohol causes dysfunction of the body which reflects the pathological findings of laboratory tests such as reducing the synthesis of proteins, changes in enzyme activity and so on (3, 4).

Table 1. Laboratory parameters: MCV, IgA, transferrin, IgA/transferrin and GGT in four groups of test subjects

\begin{tabular}{|c|c|c|c|c|c|}
\hline Laboratory analysis & $\begin{array}{l}\mathrm{MCV} \\
\mathrm{FL}\end{array}$ & $\begin{array}{l}\mathrm{IgA} \\
\mathrm{g} / \mathrm{L}\end{array}$ & $\begin{array}{c}\text { Transferrin } \\
\mathrm{g} / \mathrm{L}\end{array}$ & $\begin{array}{c}\mathrm{IgA} / \\
\text { transferrin }\end{array}$ & $\begin{array}{l}\text { GGT } \\
\text { IU/L }\end{array}$ \\
\hline Mean healthy persons $\mathrm{N}=18$ & 93.6 & 2.83 & 3.20 & 0.90 & 7.1 \\
\hline Mean treated alcoholics $\mathrm{N}=15$ & 93.8 & 2.90 & 3.10 & 0.92 & 11.4 \\
\hline Mean alcoholics $\mathrm{N}=20$ & 101.0 & 5.10 & 2.78 & 1.74 & 101.0 \\
\hline $\begin{array}{l}\text { Mean workers exposed to ethanol } \\
\mathrm{N}=15\end{array}$ & 99.6 & 1.95 & 2.80 & 1.14 & 18.7 \\
\hline
\end{tabular}

Our findings confirm the experience of other authors that the detection and control of chronic alcoholism GGT proved to be a very good parameter. The alcohol stimulates the hepatic synthesis of GGT at the cellular membrane. In our analyses, GGT activity was very high in the group of chronic alcoholics compared to the control group. In the other two groups, there was no statistical significance, because the activity of GGT in treated alcoholics who abstained for more than a year was very close to the control group. What diminishes the value of the determination of GGT activity as a screening test for the detection of alcoholics is its non-specificity, prevalence in almost all body tissues and fluids, and the inductive effect of a number of drugs on its activity.
Therefore, it is necessary to determine the level and other parameters that have been found to be influenced by changing the alcohol in the body $(5,6)$.

\section{Discussion}

Degradation of tissue in hepatocellular necrosis under the influence of alcohol causes the formation of antibodies whose presence is determined by the concentration of immunoglobulin. The tested amount of immunoglobulins A, G, and M (IgA, IgG, IgM) has significantly higher values in the group of chronic alcoholics than in the control group (as shown by $\operatorname{IgA}$ ), which is also found in other authors. The mean value of IgA in untreated alcoholics was 
significantly increased as compared to the control group, while the other groups showed no statistical difference compared to the control group. Accordingly, the $\operatorname{IgA}$ is the second parameter that would be used in screening assays for the detection and control of alcoholics.

In the group of chronic alcoholics, those with a reduced amount of transferrin were found in comparison with the control group, which is explained by alcohol-toxic liver damage which results in difficult protein synthesis and their transfer. The workers exposed to ethanol showed decreased transferrin concentration, while the mean transferrin in treated alcoholics was unchanged compared to the control group. Increased concentrations of IgA under the influence of alcohol and reduced levels of transferrin expressed by the quotient of IgA/transferrin result in an increase of the quotient which may be useful in the study of alcoholics are available as the third parameter. The ratio of IgA/transferrin in chronic alcoholics is increased with a statistical significance, as a group of workers in this ratio is slightly higher than in the control group, but without significant differences.

Finally, MCV in alcoholics showed an increase that reflects discrete anemia. MCV has increased in the group of untreated alcoholics compared to healthy persons and recovering alcoholics.

As for the workers employed in the factory of alcoholic beverages, MCV level was significantly increased compared to healthy subjects and reached a value close to that of an alcoholic.

\section{Conclusion}

The level of $\operatorname{IgA}$, transferrin, and the MCV and the ratio of $\mathrm{IgA} /$ transferrin are parameters that can be used for the detection of alcohol in parallel with the determination of GGT activity.

There was no significant difference between the treated alcoholics and healthy controls in all tested parameters, which indicates a well-chosen way of treating alcoholics.

In the group of untreated alcoholics, the value of the alcoholic IgA, MCV, and the ratio of IgA/ transferrin were increased as well as the activity of GGT (as expected) compared to the healthy individuals and treated alcoholics.

As for the workers employed in the factory of alcoholic beverages, the MCV level was significantly higher than in healthy individuals, and this value is close to that of alcoholics as a reflection of anemia. In this group, the transferrin concentration is reduced, so that the ratio of IgA/ transferrin is slightly higher than that in healthy persons, but without significant differences. Both parameters indicate chronic ethanol intoxication of workers $(7,8)$.

Looking at the results of the examined parameters, one can see that they can help in the detection of chronic alcoholics and to monitor the treatment given the fact that many alcoholics use alcohol while under treatment. In chronic alcoholic's abstinence, the increase in IgA levels and the ratio of $\operatorname{IgA}$ /transferrin, as well as the increase in the activity of the enzyme GGT provide evidence of even minor or sporadic use of alcohol, and normal levels of these parameters in the serum during the treatment of abstinence were confirmed.
1. Nikolic J, Nickovic V, Acimovic D. Contemporary aspects of the diagnostics of alcoholic liver disease: VSP 2012; 69(10):874-9. [CrossRef] [PubMed]

2. Nikolic J. Alcoholic intoxication. In: Ali Qureshi G, Parvez H, Caudy P, Parvez S, editors. Neurochemical markers of degenerative nervous diseases and drug addiction. Utrecht: VSP; 1998. p. 193-221.

3. Mathurin $P$, Abdelnour M, Ramond MJ, Carbonell N, Fartoux L, Serfaty $L$ et al. Early change in bilirubin levels is an important prognostic factor in severe alcoholic hepatitis treated with prednisolone. Hepatology 2003; 38(6):1363-9. [CrossRef] [PubMed]

4. Sillanaukee $P$, Olsson U. Improved diagnostic classification of alcohol abusers by combining carbohydratedeficient transferrin and gamma-glutamyltransferase. Clin Chem 2001; 47(4):681-5. [CrossRef] [PubMed]
5. Nomura F, Itoga S. Transferrin (Tf), carbohydratedeficient transferrin (CDT). Nihon Rinsho 2004; 62 Suppl 11: 240-3. [PubMed]

6. Everitt $H$. The effect of acute alcohol exposure on hepatic oxidative stress and function: prevention by micronutrients. [dissertation]. Westminster: University of Westminster, School of Electronics and Computer Science; 2010.

7. Bulmer RD, Pointers Towards. Early Detection of Alcoholism, Can Fam Physician 1980; (28):259-61. [PubMed]

8. Enoch MA, Godlberg D. Problem Drinking and Alcoholism: Diagnosis and Treatment. Am Fam Physician 2002; 65(3):441-9. [PubMed] 


\title{
RANO OTKRIVANJE POTENCIJALNOG HRONIČNOG ALKOHOLIZMA ODREĐIVANJEM NIVOA IGA, MCV I TRANSFERINA
}

\author{
Muhamed Sarvan ${ }^{1}$, Sonja Ketin ${ }^{2}$, Radmila Maksimović ${ }^{1}$, Rade Biočanin ${ }^{1}$
}

${ }^{1}$ Farmaceutsko zdravstveni fakultet, Travnik, Bosna i Hercegovina

${ }^{2}$ Visoka brodarska škola akademskih studija Beograd, Srbija

Kontakt: Sonja Ketin

Bulevar vojvode Putnika 7, 11000 Belgrade, Srbija

E-mail: ketin.sonja@gmail.com

Nivo IgA, MCV i transferina, kao i odnos IgA i transferina, korišćeni su parametri za detekciju hroničnog alkoholizma. Paralelno sa time određivana je aktivnost GGT. Četiri grupe ispitanika obrađivano je za ovo istraživanje: zdrave osobe $(\mathrm{N}=18)$, hronični alkoholičari $(\mathrm{N}=$ 20), lečeni hronični alkoholičari $(N=15)$ i najzad grupa radnika zaposlenih u fabrici alkoholnih pića $(\mathrm{N}=15)$. Neparametrijski Mann-Whitney U-test korišćen je za procesuiranje dobijenih vrednosti. Nije bilo značajnije razlike između lečenih alkoholičara i zdravih osoba u svim ispitivanim parametrima (srednja vrednost kod lečenih alkoholičara: IgA $=2,9 \mathrm{~g} / \mathrm{L} ; \mathrm{MCV}=$ 93,8; transferin = 3,1 g/L; IgA/transferin = 0,92; GGT = 11,4U $/ \mathrm{L} ;$ zdrave osobe: $\operatorname{IgA}=2,83$ $\mathrm{g} / \mathrm{L} ; \mathrm{MCV}=93,6 ;$ transferin = 3,2 g/L; IgA/transferin = 0,9; GGT = 7,1 U/L).U grupi nelečenih alkoholičara vrednosti IgA, MCV i odnos IgA i transferin povećane su kao što je povećana i aktivnost GGT (što je uobičajeno) u odnosu na aktivnost GGT kod zdravih osoba i lečenih alkoholičara (alkoholičari: IgA $=5,1 \mathrm{~g} / \mathrm{L} ; \mathrm{MCV}=101 ;$ transferin $=2,78 \mathrm{~g} / \mathrm{L}$. $\mathrm{IgA} /$ transferin $=1,74 ; \mathrm{GGT}=101,4 \mathrm{U} / \mathrm{L}$ ). Što se tiče radnika zaposlenih u fabrici alkoholnih pića, nivo MCV značajno je povećan u odnosu na nivo kod zdravih osoba i ta je vrednost bliska onoj kod alkoholičara (radnici: IgA = 1,95 g/L; MCV = 99,6; transferin = 2,8 g/L; $\mathrm{IgA} /$ transferin $=1,14 ; \mathrm{GGT}=18,7 \mathrm{U} / \mathrm{L})$. Koncentracija transferina smanjena je kod radnika, pa je i odnos IgA/ transferin neznatno viši nego kod zdravih osoba, ali bez značajne razlike. Može se videti da dobijeni rezultati ispitivanih parametara mogu pomoći ne samo za otkrivanje hroničnog alkoholizma, već i za praćenje lečenja, imajući u vidu činjenicu da mnogi alkoholičari koriste alkohol dok su podvrgnuti tretmanu.

Acta Medica Medianae 2020;59(1):60-63.

Ključne reči: hronična bolest, alkoholizam, eritrocitni indeksi, MCV, transferin IgA, rano otkrivanje 